\title{
Iva imbricata
}

\section{seacoast marshelder}

\section{Asteraceae}

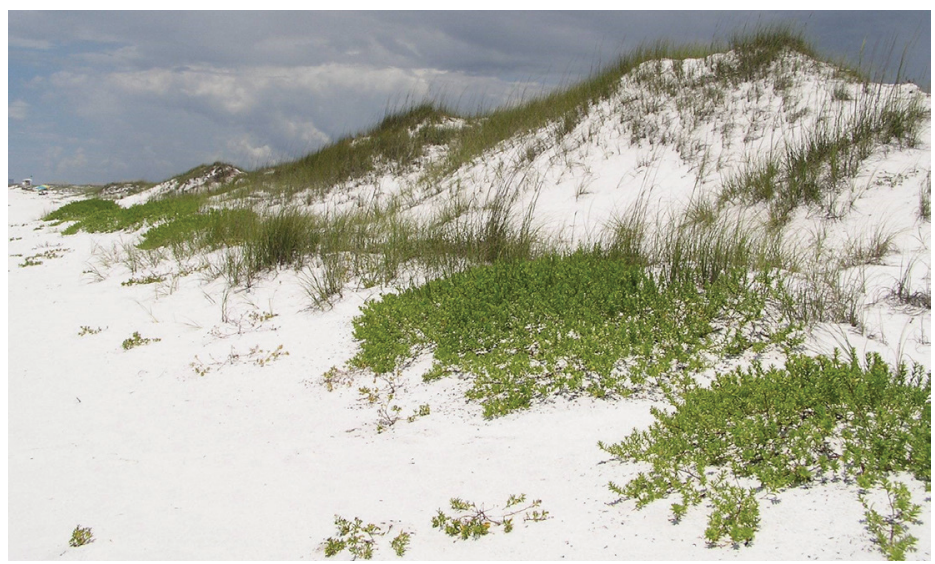

Credit: Josiah Raymer, UF/IFAS

Seacoast marshelder is an important plant for dune restoration, stabilization, and formation because of its ability to trap sand. It grows on foredunes and forms low, rounded dunes as sand accumulates (Craig 1991). As the aboveground portions of the plant become buried by sand, rooting is stimulated in stem tissue (Craig 1975). This gives the appearance that the plant is rhizomatous when in fact it is the sand burial resulting in the presence of below-ground stems. This plant occurs throughout coastal Florida (except for the Big Bend coast) and in coastal southeastern states west to Texas and northeast to Virginia.

\section{General Description}

Seacoast marshelder is a sparsely branched, succulent, shrub-like perennial herb that can reach heights of 1 to $4 \mathrm{ft}$ and widths up to $6 \mathrm{ft}$. Leaves are without stalks, succulent, lance shaped, and mostly arranged oppositely (at the base of the plant) early in the season and become alternate (near the top of the plant) later in the season. Leaves are 0.75 to 2 in long with blades narrowing at tip and have almost entire margins. Inflorescences are non-showy terminal racemes that appear in late summer and continue to elongate through early fall with leaf-like bracts below initial flowers and smaller bracts below later flowers. Flowers have cream to white to greenish petals that are $1.5 \mathrm{~mm}$ long. Fruits are achenes, 3.5 to $5 \mathrm{~mm}$ long, brown to yellow, and globe shaped. Seeds are retained in the dried calyxes of the flowers throughout the winter months until the plants begin to break apart and the seeds are dispersed as the plant parts are blown by beach breezes.

\section{Propagation}

Cutting propagation of seacoast marshelder is possible with 2- and 4-in stem cuttings. Cuttings obtained from early season flushes of growth that are flexible but not stiff (softwood cuttings) root with greater than $70 \%$ success without auxin application. Short lateral stems may be used to prepare 2-in cuttings and a quick-dip in 1,000 ppm IBA (Indole-3-butyric acid) will improve rooting for these lateral cuttings (Thetford and Miller 2002). Additionally, the success of rooting (rooting percentage) and quality of shoot tip cuttings (root number and root length) are variable across seasons (Raymer et al. 2008).

The following cutting propagation protocol is adapted from Thetford and Miller (2004). Collect 4-in softwood cuttings from the tips of non-branched terminal shoots in early spring through summer. Cuttings should not be collected from floral portions of the stem because these portions of the stem have no lateral buds from which to initiate new vegetative shoots. Cuttings may be rooted in 72 -cell flats under mist for 3 to 4 weeks followed by hand watering for another 2 to 3 weeks in a well-draining substrate such as a commercial potting mix or $100 \%$ milled pine bark. Rooted cuttings may be fertilized with a complete fertilizer using a rate of $150 \mathrm{ppm} \mathrm{N}$ solution applied 1 to 2 times a week. Plants can be pruned to stimulate branching starting week 4 or 5 or up to 1 week after transplanting to larger pots. Plants perform well in 4 -in and 1-qt pots and require 4 to 6 weeks of additional growth to develop a full rootball and a canopy of 6-8 in.

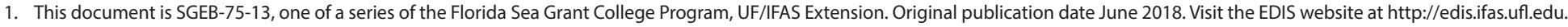

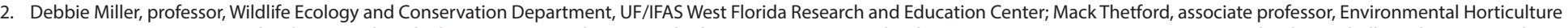

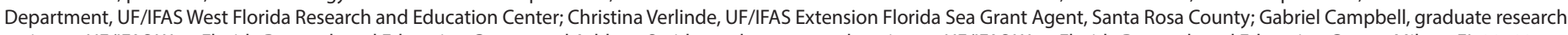

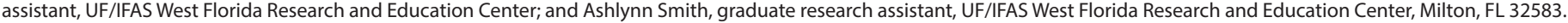




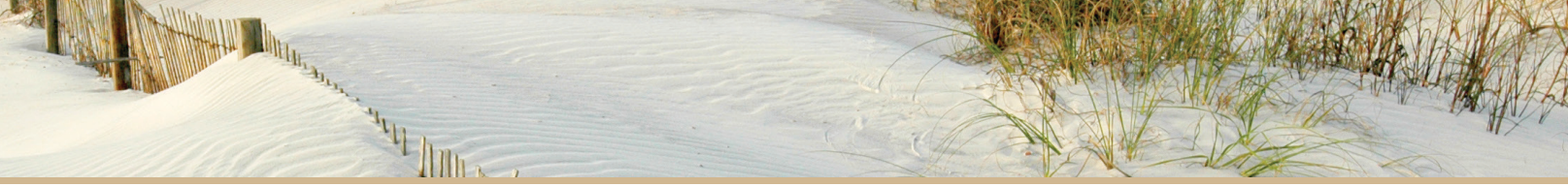

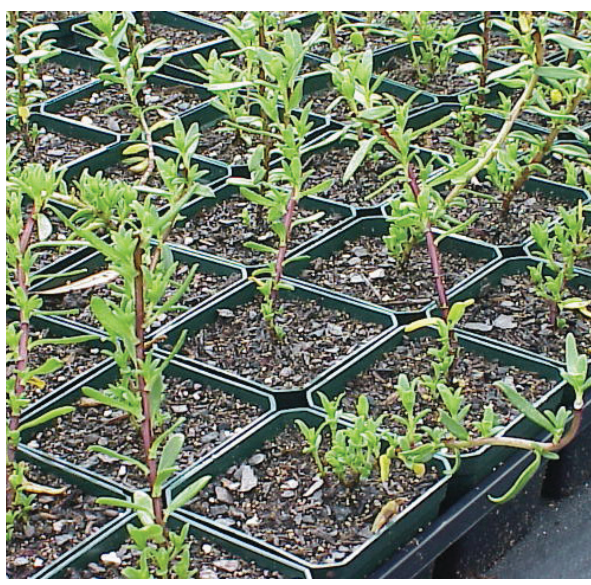

Credit: Josiah Raymer, UF/IFAS

Establishing productive nursery stock plants is possible for seacoast marshelder. The following is adapted from Raymer et al. (2008). Stock plants may be grown in 1-gal containers using a pine-bark substrate amended with 6 $\mathrm{lb} / \mathrm{yd}^{3}$ dolomitic limestone with $11 \mathrm{gm}$ (recommend rate) of a $15 \mathrm{~N}-3.9 \mathrm{P}-10 \mathrm{~K}$ controlled-release fertilizer. Stock plants started in the spring from dormant liners have the most productive cuttings when taken during May to early June and August while stock plants established from actively growing liners are most productive from September to November. Every effort should be made to increase plant width by pruning during early spring and summer and cutting harvest should be planned from May to early June. July should be a period to allow for vegetative growth before any subsequent harvests.

Seeds from a North Carolina population had physiological dormancy that was alleviated with cold stratification for at least 30 days at 4C (Van Der Valk 1974). The stratified seed then needed to be germinated with daily alternating temperatures of $10 / 15$ or $15 / 25^{\circ} \mathrm{C}$, in light or dark, to achieve high germination percentages. Seeds can be collected and readily germinate in fall (Graetz 1973). Similarly, seeds collected by the authors in fall, placed

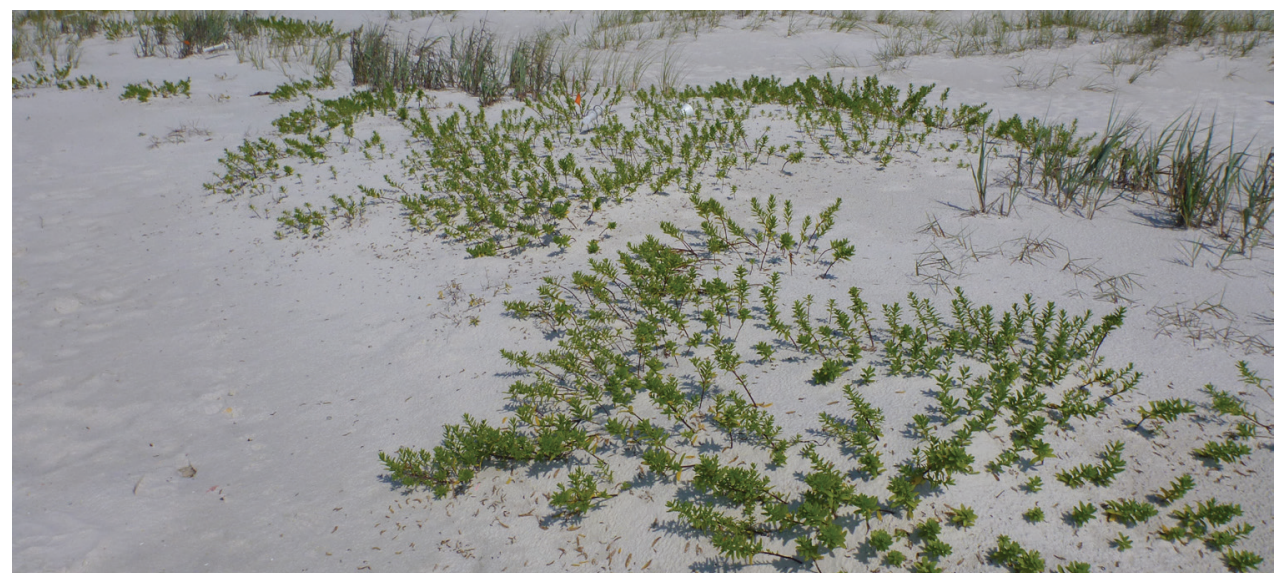

Credit: Josiah Raymer, UF/IFAS

in a plastic bag, and stored at ambient temperature for 3 months germinated readily under intermittent mist.

\section{Outplanting}

Plants should be planted well above the mean high tide line on Gulf-facing foredunes. Small, one-year-old transplants have been successfully transplanted in early spring (Graetz 1973). The authors have successfully transplanted plants produced in 4 -inch pots using a pine-bark substrate at nearly $100 \%$ survival in foredune locations both alone and in conjunction with other foredune grasses (Stoddard et al. 2014).

\section{Literature Cited}

Craig, R.M. 1975. "Woody vegetation for coastal dune areas." Proceedings of the Florida State Horticultural Society. 88:428-434.

Craig, R.M.1991. "Plants for coastal dunes of the Gulf and south Atlantic coasts and Puerto Rico." USDA SCS. Agriculture Information Bulletin, Issue no. 460.

Graetz, K.E. 1973. "Seaside plants of the Carolinas." USDA, SCS, and University of North Carolina Sea Grant Program. Sea Grant Publication.
Raymer, J., M. Thetford, and D.L. Miller. 2008. "Fertility rate of seacoast marshelder stock plants influences cutting production and rooting characteristics of stem cuttings." HortTechnology. 18(3):372-378.

Stoddard, M., D.L. Miller, L.C. Branch, and M. Thetford. 2014.

"Endangered beach mouse: Linking population studies/ habitat restoration to predict sea level rise." Final Report submitted to Gulf Islands National Seashore, Gulf Coast Cooperative Ecosystems Studies Unit Project H5000 02 A271. 130 p.

Thetford, M., and D.L. Miller. 2004. Propagation and production of seacoast marshelder. ENH-975. Gainesville: University of Florida Institute of Food and Agricultural Sciences. https://edis.ifas. ufl.edu/ep232

Thetford, M., and D.L. Miller. 2002. "Propagation of four Florida coastal dune species." Native Plants Journal. 3(2):112-120.

Van Der Valk, A.G. 1974.

"Environmental factors controlling the distribution of forbs on coastal foredunes in Cape Hatteras, National Seashore." Canadian Journal of Botany. 52:1057-1073. 